\title{
Differential tissue accumulation of arsenic and heavy metals from diets in three edible fish species
}

\author{
N.F. SCHENONE ${ }^{1,2}$, L. VACKOVA ${ }^{3}$ \& A. FERNANDEZ CIRELLI ${ }^{1,2}$ \\ ${ }^{1}$ Facultad de Ciencias Veterinarias, Centro de Estudios Transdisciplinarios del Agua (CETA), Universidad de Buenos Aires, \\ Buenos Aires, Argentina; ${ }^{2}$ Consejo Nacional de Investigaciones Cientificas y Técnicas (CONICET), Ciudad Autónoma \\ de Buenos Aires, Buenos Aires, Argentina; ${ }^{3}$ Department of Water Technology and Environmental Engineering, Faculty of \\ Environmental Technology, Institute of Chemical Technology Prague, Praha, Czech Republic
}

\begin{abstract}
Three different commercial fish species Odontesthes bonariensis, Rhamdia quelen and Oreochromis niloticus and fish feed were collected from four aquaculture farms. Heavy metal $(\mathrm{Cd}, \mathrm{Cr}, \mathrm{Cu}, \mathrm{Fe}, \mathrm{Mn}, \mathrm{Pb}$ and $\mathrm{Zn})$ and arsenic concentration were determined by inductively coupled plasmaoptical emission spectrometry (ICP-OES) in muscle, liver, gonad, skin, scale and fat from fish and in feed diets. Arsenic concentration was found in different tissues differing between species and within $O$. bonariensis. $\mathrm{Cd}$ was differentially accumulated in liver in $O$. bonariensis and $R$. quelen; however, in O. niloticus $\mathrm{Cd}$ was found in muscle and scales. Higher concentrations of $\mathrm{Cr}$ were determined in skin and scales of $O$. bonariensis and O. niloticus. $\mathrm{Cu}, \mathrm{Fe}$, $\mathrm{Mn}$ and $\mathrm{Zn}$ were found in all tissues being $\mathrm{Cu}$ and Fe concentrations higher in liver. Mn was differentially accumulated in $O$. bonariensis scales, however in $R$. quelen no significant differences were found and in O. niloticus liver was the main accumulation tissue. $\mathrm{Zn}$ concentration was higher in gonad, skin and liver from $R$. quelen and $O$. bonariensis, and in $O$. niloticus the highest concentration was found in scales. All the results were below the international limits for food safety except for the concentration of $\mathrm{Cd}$ in muscle and scales of $O$. niloticus.
\end{abstract}

KEY WORDS: accumulation, arsenic, fish tissue, heavy metals

Received 23 July 2012; accepted 15 April 2013

Correspondence: N.F. Schenone and A. Fernandez Cirelli, Facultad de Ciencias Veterinarias, Centro de Estudios Transdisciplinarios del Agua (CETA), Universidad de Buenos Aires, Av. Chorroarín 280, CP1427 Buenos Aires, Argentina. E-mails: nschenone@fvet.uba.ar, afcirelli@gmail.com

\section{Introduction}

Arsenic and heavy metals constitute a central group of aquatic contaminants due to the toxicity, high persistence and bioaccumulative properties in the food chain (Ikem \& Egiebor 2005). Heavy metal concentration in fish has been studied in many countries around the world and becomes of particular interest due to the intimate relation with human health through consumption (Dural et al. 2007; CastroGonzález \& Méndez-Armenta 2008; Herreros et al. 2008; Uysal et al. 2008). Bioaccumulation of heavy metals occurs in several tissues of aquatic organisms and may become toxic for fish and also for people when it reaches a substantially high level (Dural et al. 2007). The uptake of these pollutants is commonly related to its concentration in water and the trophic chain in natural aquatic environments; however, in confined farming environment the feed stuff becomes a key factor as a point source. The biomagnification of metals and trace elements results from the combination of gastrointestinal absorption efficiency and the transference rate to different tissues, among other factors (Kelly et al. 2008). Fish consumption is associated with a healthy diet due to the high contents of essential polyunsaturated fatty acids of the omega-3 family; however, fish constitute an important source of heavy metal and other contaminants (Gladyshev et al. 2009). The presence of these contaminants in fish feed may lead to an increase in fish products, thus a risk for production and for human consumption. Arsenic presence was reported in fish feed products to limit levels close to be excluded from the market (Sloth et al. 2005).

The nutrients, as well as contaminants, found in fish flesh are derived largely from the feed and, thus, farmed fish can be tailored to provide optimal levels of fatty acids, and selected vitamins and minerals for human consumption (Gordon Bell \& Waagbø 2008). 
Arsenic is a natural pollutant in Argentina affecting soils and surface and groundwater in natural environments (Rosso et al. 2011). In previous studies, trace elements were determined in source and effluent water from fish farms showing an increase of some elements which were not present in source water and may come from fish feed (Schenone et al. 2011). For these reasons, determination of chemical quality on fish feed and fish from aquaculture has become an emerging concern. However, the information available regarding this matter is scarce.

The aim of this study was to investigate the distribution of trace elements in fish feed and in different tissues of farmed fish. For this purpose, fish feed and three different fish species from four aquaculture sites, three in Buenos Aires province and one in Corrientes province (Fig. 1) were collected. Corrientes province is located in the northeast region of Argentina and has less agricultural and anthropic influence. However natural arsenic contamination in water and heavy metals in fish diets may contribute to the concentration of these elements in fish tissues. As, $\mathrm{Cd}, \mathrm{Cr}, \mathrm{Cu}$, $\mathrm{Fe}, \mathrm{Mn}, \mathrm{Pb}$ and $\mathrm{Zn}$ were measured in muscle, liver, gonad, skin, scale and fat from fish samples and in fish feed due to the presence of these elements in water (Schenone et al. 2011). Catfish, Rhamdia quelen (Quoy \& Gaimard) and Silverside, Odontesthes bonariensis (Valenciennes) are two of the native species studied in this study and Tilapia, Oreochromis niloticus (Quoy \& Gaimard) as non-native specie.

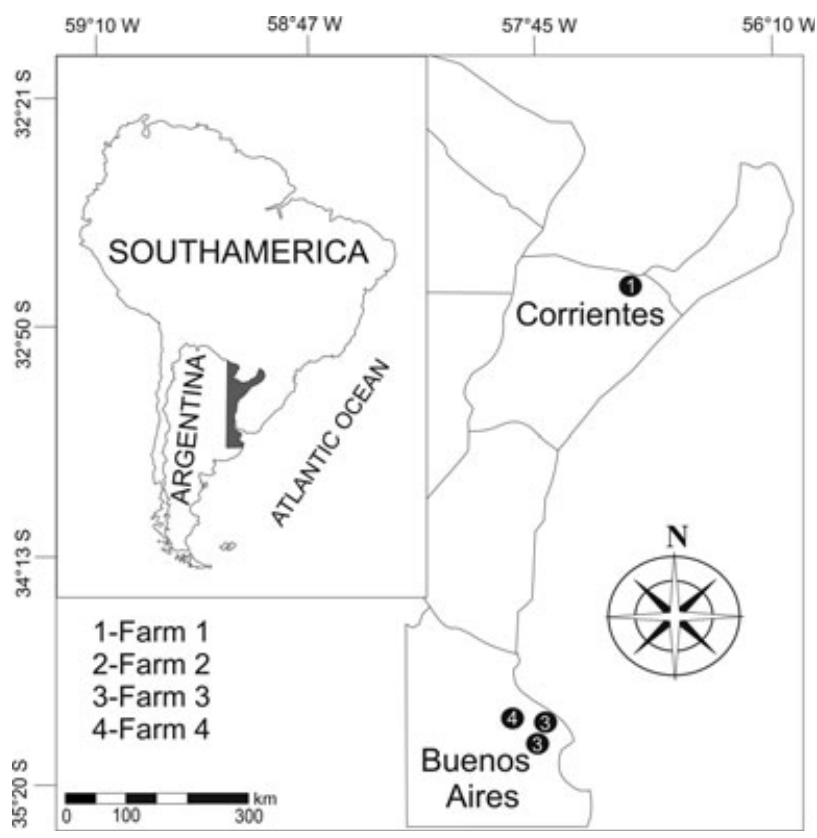

Figure 1 Map with the respective farms location.
This research on heavy metals and arsenic in aquaculture diets and products reports for the first time the differential concentration in tissues and the feed effect on the production in this region.

\section{Materials and methods}

\section{Study area and fish samples}

Fish samples from three different commercial species and fish feeds were obtained from local production farms in Buenos Aires and Corrientes province (Fig. 1). Due to the climatic conditions Corrientes province is more suitable for $R$. quelen production (Farm 1) and Buenos Aires for O. bonariensis (Farms 2 and 3). Oreochromis niloticus from farm 4 correspond to an intensive indoor production system to reach optimum culture temperatures (Table 1).

A total of three fish from each site were randomly captured from production ponds using hand nets, placed on ice and transported to the laboratory the same day. Fish were killed with percussive stunning (Van de Vis et al. 2003). Each sample collected from the farms was dissected for its muscle, liver, gonad, skin, scale and fat. To prevent metal contamination of the samples by the laboratory equipments, special care was taken and tissues were dissected by plastic knife and all laboratory ware was soaked in $10 \% \mathrm{HNO}_{3}$ for $48 \mathrm{~h}$, and rinsed five times with distiled water, and then five times with ultra pure Milli-Q water prior to use (Turkmen \& Ciminli, 2007). Each tissue was stored in plastic bags at $-20{ }^{\circ} \mathrm{C}$ prior to preparation. Feed sample were collected in Ziploc $^{\mathrm{R}}$ bags from each farm, approximately $1 \mathrm{~kg}$.

\section{Sample preparation}

During fish dissection, muscle, skin and gonad tissue were cut in small slices to improve digestion. Scale and fat were directly digested. The tissue samples and feed samples were digested with concentrated nitric acid. A portion of

Table 1 Size and weight of fish from the sampled farms

\begin{tabular}{|c|c|c|c|c|}
\hline Location & Species & Scientific & $\begin{array}{l}\text { Size } \\
\text { range } \\
(\mathrm{cm})\end{array}$ & $\begin{array}{l}\text { Weight } \\
\text { rage }(\mathrm{g})\end{array}$ \\
\hline arm 1 & Catf & Rha & $22-24$ & $276-290$ \\
\hline Farm 2 & Silverside & Odontesthes bonariensis & $25-27$ & $240-263$ \\
\hline Farm 3 & Silverside & Odontesthes bonariensis & $24-26$ & $250-255$ \\
\hline Farm 4 & Tilapia & Oreochromis niloticus & $16-18$ & $190-200$ \\
\hline
\end{tabular}


the dissected sample (2 g) was oven dry till constant weight and then transferred to a $100 \mathrm{~mL}$ beaker. Thereafter, $10 \mathrm{~mL}$ of concentrated $\mathrm{HNO}_{3}$ was added to the sample. The beaker was covered with a watch glass and the sample heated at $200{ }^{\circ} \mathrm{C}$ on a hot plate for $3 \mathrm{~h}$. The solution was evaporated slowly to near dryness. By repeating the digestion twice, all organic matter in every sample was completely digested. After cooling, a further $1 \mathrm{~mL}$ of concentrated $\mathrm{HNO}_{3}$ was added to dissolve inorganic matter and the beaker rinsed with Milli-Q water. The solution was quantitatively transferred to a final volume of $50 \mathrm{~mL}$ in polyethylene tube. Before analysis, the samples were filtered through a $0.45 \mu \mathrm{m}$ nitrocellulose membrane filter (Alam et al. 2002). Analytical blanks were run in the same way as the samples and determined using standard solutions $\left(\right.$ Merck $^{\mathrm{R}}$, multi element standard) prepared in the same acid matrix. Certify reference material DORM-2 (National Research Council Canada, Ottowa, ON, Canada) was analysed to assure accuracy and recovery rates. All chemical used in this study were obtained from Merck $^{\mathrm{R}}$ analytical grade (Table 2).

\section{Sample analysis}

All samples were analysed by Perking Elmer (Waltham, MA, USA) Optima 2000 DV inductively coupled plasmaoptical emission spectrometry (ICP-OES). The concentrations of $\mathrm{As}, \mathrm{Cd}, \mathrm{Cr}, \mathrm{Cu}, \mathrm{Fe}, \mathrm{Mn}, \mathrm{Pb}$ and $\mathrm{Zn}$ were determined. The concentrations were calculated on a wet weight basis for fish tissue.

\section{Data analysis}

Each reported result was the average of three analyses. The results were shown as mean $\pm \mathrm{SD}$. One-way ANOvA was utilized to compare the concentrations among tissues with

Table 2 Concentrations of elements (means \pm SE, in $\mathrm{mg} \mathrm{kg}^{-1}$ dry wt, $n=3$ ) found in certified reference material DORM-2 (dogfish muscle, NRC, Canada)

\begin{tabular}{lccc}
\hline Element & Certified values & Measured values & Recovery $(\%)$ \\
\hline As & $18.0 \pm 1.1$ & $16.4 \pm 1.3$ & 91 \\
$\mathrm{Cd}$ & $0.043 \pm 0.008$ & $0.046 \pm 0.012$ & 109 \\
$\mathrm{Cr}$ & $34.7 \pm 5.5$ & $33.5 \pm 1.48$ & 97 \\
$\mathrm{~Pb}$ & $0.065 \pm 0.007$ & $0.067 \pm 0.009$ & 103 \\
$\mathrm{Cu}$ & $2.34 \pm 0.16$ & $2.32 \pm 0.21$ & 99 \\
$\mathrm{Fe}$ & $142 \pm 10$ & $137 \pm 11.5$ & 96 \\
$\mathrm{Mn}$ & $3.66 \pm 0.34$ & $3.46 \pm 0.46$ & 95 \\
$\mathrm{Zn}$ & $25.6 \pm 2.3$ & $23.9 \pm 1.85$ & 93 \\
\hline
\end{tabular}

Tukey's contrast using InfoStat statistic program. Results were considered significant at $P<0.05$.

\section{Results}

As and heavy metal concentration in catfish ( $R$. quelen) and feed from farm 1 are shown in Table 3. The presence of As was detected in muscle, liver and gonad but there were no significant differences, although the concentration in feed was below the detection limit. Arsenic concentration in muscle should be of particular interest due to human consumption. Cd was detected in fish feed and liver, however in the other tissues was below the detection limit. $\mathrm{Cr}$ was detected in fish feed and in all the tissues. The highest $\mathrm{Cr}$ concentration was found in gonad. $\mathrm{Pb}$ concentrations were below detection limit in all tissues and fish feed. $\mathrm{Cu}$, $\mathrm{Fe}, \mathrm{Mn}$ and $\mathrm{Zn}$ can be considered as micronutrients; however, in high concentrations they can be toxic. The $\mathrm{Cu}$ accumulation was higher in liver and lower in the other tissues. The highest $\mathrm{Fe}$ value was found in liver followed by the concentration in gonad; muscle, skin and fat did not show significant differences. Mn concentration did not show significant difference; however, liver showed a higher accumulation tendency. Zn highest value was observed in gonad, the other tissues had lower concentrations with no significant differences.

As and heavy metal concentrations in $O$. bonariensis and fish feed from farm 2 are shown in Table 4. Arsenic was found in muscle and liver and also in fish feed. $\mathrm{Cd}$ was detected in fish feed and showed a differential accumulation in liver and in the other tissues was below the detection limit, the same pattern was observed in $R$. quelen. Fish feed showed a high $\mathrm{Cr}$ concentration. The higher $\mathrm{Cr}$ concentration was found in scales and also was observed in muscle and gonad in lower concentration. $\mathrm{Pb}$ was below the detection limit in all tissues; however, it was detected in fish feed. $\mathrm{Cu}$ was observed in all tissues but there were no significant differences. Fe was detected in all tissue samples and was higher in liver and gonad, and the lower value was found in muscle. Mn concentration showed a significantly higher concentration in scale than in the other tissues. $\mathrm{Zn}$ was differentially accumulated in skin while muscle showed the lower value.

As and heavy metal concentrations in O. bonariensis and fish feed from farm 3 are shown in Table 5. Arsenic concentration was only detected in skin even though a high concentration was observed in feed a different pattern was observed in farm 2. Cd showed a differential accumulation in liver, and it was detected in fish feed. The same pattern 
Table 3 Trace elements concentration $\left(\mathrm{mg} \mathrm{kg}^{-1} \mathrm{ww}\right)(\mathrm{mean} \pm \mathrm{SD})$ in different tissues of Rhamdia quelen from farm 1

\begin{tabular}{|c|c|c|c|c|c|c|c|}
\hline & Muscle & Liver & Fat & Gonad & Skin & scale & Feed \\
\hline \multicolumn{8}{|c|}{ Rhamdia quelen (Farm 1) } \\
\hline As & $0.55 \pm 0.18^{a}$ & $0.22 \pm 0.08^{a}$ & bdl & $0.38 \pm 0.13^{a}$ & bdl & nd & bdl \\
\hline $\mathrm{Cd}$ & bdl & $0.31 \pm 0.23$ & bdl & bdl & bdl & nd & $0.24 \pm 0.08$ \\
\hline $\mathrm{Cr}$ & $0.10 \pm 0.01^{\mathrm{b}}$ & $0.14 \pm 0.03^{b}$ & $0.08 \pm 0.03^{b}$ & $0.23 \pm 0.02^{a}$ & $0.11 \pm 0.03^{b}$ & nd & $1.57 \pm 0.22$ \\
\hline $\mathrm{Pb}$ & bdl & bdl & bdl & bdl & bdl & nd & bdl \\
\hline $\mathrm{Cu}$ & $0.42 \pm 0.03^{b}$ & $16.64 \pm 7.50^{a}$ & $0.40 \pm 0.16^{\mathbf{b}}$ & $1.58 \pm 0.46^{\mathbf{b}}$ & $2.55 \pm 0.71^{b}$ & nd & $77.38 \pm 17.35$ \\
\hline $\mathrm{Fe}$ & $8.92 \pm 3.68^{c}$ & $357.72 \pm 82.56^{a}$ & $19.25 \pm 5.10^{c}$ & $134.51 \pm 24.82^{b}$ & $28.93 \pm 5.65^{c}$ & nd & $223.82 \pm 19.77$ \\
\hline $\mathrm{Mn}$ & $0.85 \pm 0.61^{a}$ & $1.88 \pm 0.40^{\mathrm{a}}$ & $0.91 \pm 0.90^{\mathrm{a}}$ & $0.99 \pm 0.57^{\mathrm{a}}$ & $0.61 \pm 0.14^{\mathrm{a}}$ & nd & $434.53 \pm 24.92$ \\
\hline $\mathrm{Zn}$ & $8.39 \pm 1.26^{\mathbf{b}}$ & $27.00 \pm 8.91^{b}$ & $2.37 \pm 0.47^{b}$ & $129.06 \pm 29.31^{a}$ & $28.94 \pm 4.09^{b}$ & nd & $625.98 \pm 2.88$ \\
\hline
\end{tabular}

bdl, below detection limit; nd, not determined.

Values with non-common letter superscript are significantly different $(P<0.05)$.

Table 4 Trace elements concentration $\left(\mathrm{mg} \mathrm{kg}^{-1} \mathrm{ww}\right)$ (mean $\pm \mathrm{SD}$ ) in different tissues of Odondetesthes bonariensis from farm 2

\begin{tabular}{|c|c|c|c|c|c|c|c|}
\hline & Muscle & Liver & Fat & Gonad & Skin & Scale & Feed \\
\hline \multicolumn{8}{|c|}{ Odontesthes bonariensis (Farm 2) } \\
\hline As & $0.47 \pm 0.05^{a}$ & $0.67 \pm 0.29^{a}$ & nd & bdl & bdl & bdl & $2.65 \pm 0.35$ \\
\hline $\mathrm{Cd}$ & bdl & $1.70 \pm 0.56$ & nd & bdl & bdl & bdl & $2.07 \pm 0.21$ \\
\hline $\mathrm{Cr}$ & $0.19 \pm 0.03^{b}$ & bdl & nd & $0.37 \pm 0.06^{\mathbf{b}}$ & bdl & $0.93 \pm 0.24^{\mathrm{a}}$ & $1.52 \pm 0.25$ \\
\hline $\mathrm{Pb}$ & bdl & bdl & nd & bdl & bdl & bdl & $0.39 \pm 0.08$ \\
\hline $\mathrm{Cu}$ & $1.10 \pm 0.07^{a}$ & $1.74 \pm 0.12^{\mathrm{a}}$ & nd & $1.04 \pm 0.38^{a}$ & $1.16 \pm 0.27^{a}$ & $1.32 \pm 0.47^{a}$ & $\mathrm{Nd}$ \\
\hline $\mathrm{Fe}$ & $6.92 \pm 0.78^{c}$ & $20.09 \pm 5.44^{\mathrm{ab}}$ & nd & $24.19 \pm 2.99^{a}$ & $17.02 \pm 2.62^{\mathrm{ab}}$ & $9.40 \pm 3.15^{b c}$ & $\mathrm{Nd}$ \\
\hline $\mathrm{Mn}$ & $0.44 \pm 0.03^{b}$ & $1.196 \pm 0.27^{\mathbf{b}}$ & nd & $1.10 \pm 0.51^{\mathrm{b}}$ & $1.538 \pm 0.21^{b}$ & $24.03 \pm 4.12^{\mathrm{a}}$ & $\mathrm{Nd}$ \\
\hline $\mathrm{Zn}$ & $8.75 \pm 1.28^{c}$ & $18.42 \pm 2.49^{b}$ & nd & $14.50 \pm 2.65^{b c}$ & $40.13 \pm 7.27^{\mathrm{a}}$ & $14.21 \pm 2.46^{b c}$ & $\mathrm{Nd}$ \\
\hline
\end{tabular}

bdl, below detection limit; nd, not determined.

Values with non-common letter superscript are significantly different $(P<0.05)$.

Table 5 Trace elements concentration $\left(\mathrm{mg} \mathrm{kg}^{-1}\right.$ ww) (mean $\pm \mathrm{SD}$ ) in different tissues of Odondetesthes bonariensis from farm 3

\begin{tabular}{|c|c|c|c|c|c|c|c|}
\hline & Muscle & Liver & Fat & Gonad & Skin & Scale & Feed \\
\hline \multicolumn{8}{|c|}{ Odontesthes bonariensis (Farm 3) } \\
\hline As & bdl & bdl & nd & bdl & $0.61 \pm 0.01$ & bdl & $2.49 \pm 0.15$ \\
\hline $\mathrm{Cd}$ & bdl & $0.28 \pm 0.01$ & nd & bdl & bdl & bdl & $1.95 \pm 0.17$ \\
\hline $\mathrm{Cr}$ & $0.12 \pm 0.01^{b}$ & bdl & nd & $0.24 \pm 0.01^{b}$ & $0.27 \pm 0.02^{\mathbf{b}}$ & $1.02 \pm 0.24^{\mathrm{a}}$ & $1.21 \pm 0.37$ \\
\hline $\mathrm{Pb}$ & bdl & bdl & nd & bdl & bdl & bdl & $0.60 \pm 0.28$ \\
\hline $\mathrm{Cu}$ & $0.32 \pm 0.01^{\mathrm{d}}$ & $1.35 \pm 0.11^{b}$ & nd & $1.08 \pm 0.20^{\mathrm{bc}}$ & $2.09 \pm 0.24^{\mathrm{a}}$ & $0.93 \pm 0.03^{c}$ & nd \\
\hline $\mathrm{Fe}$ & $4.76 \pm 0.26^{\mathrm{d}}$ & $62.78 \pm 5.33^{a}$ & nd & $32.00 \pm 2.43^{d}$ & $10.96 \pm 1.65^{\mathrm{cd}}$ & $15.64 \pm 3.44^{c}$ & nd \\
\hline $\mathrm{Mn}$ & $0.25 \pm 0.04^{b}$ & $1.14 \pm 0.19^{b}$ & nd & $0.93 \pm 0.13^{b}$ & $0.67 \pm 0.07^{\mathbf{b}}$ & $16.89 \pm 2.16^{a}$ & nd \\
\hline $\mathrm{Zn}$ & $6.04 \pm 0.35^{c}$ & $14.30 \pm 0.82^{b}$ & nd & $25.28 \pm 4.09^{a}$ & $21.26 \pm 4.65^{\mathrm{ab}}$ & $16.74 \pm 1.14^{b}$ & nd \\
\hline
\end{tabular}

bdl, below detection limit; nd, not determined.

Values with non-common letter superscript are significantly different $(P<0.05)$.

was observed in $R$. quelen (farm 1) and $O$. bonariensis (farm 2). With regard to $\mathrm{Cr}$, there was a significantly higher concentration in scale than in muscle, gonads and skin. In liver, the concentration was below the detection limit. $\mathrm{Cr}$ concentration in feed was similar to farm 2 feed. This result is similar to that obtained in $O$. bonariensis (farm 2), where the highest accumulation occurs in scales. It is known that some fish species accumulate metals in mucus and thus, its relation with scales (Maunder et al.
2011). The highest concentration of $\mathrm{Cu}$ was observed in skin, differing significantly from other tissues. The lowest $\mathrm{Cu}$ concentration was observed in muscle. Fe concentration was significantly higher in liver than in other tissues. The lower Fe concentration was observed in muscle. This differential accumulation in the liver is consistent with that observed in farm 1 and 2. With respect to $\mathrm{Mn}$, the highest concentration was observed in scales as in $O$. bonariensis from farm 2. The other tissues showed lower concentra- 
Table 6 Trace elements concentration $\left(\mathrm{mg} \mathrm{kg}^{-1} \mathrm{ww}\right)($ mean $\pm \mathrm{SD})$ in different tissues of Oreochromis niloticus from farm 4

\begin{tabular}{|c|c|c|c|c|c|c|c|}
\hline & Muscle & Liver & Fat & Gonad & Skin & Scale & Feed \\
\hline \multicolumn{8}{|c|}{ Oreochromis niloticus (Farm 4) } \\
\hline As & bld & bdl & bdl & nd & nd & bdl & bdl \\
\hline $\mathrm{Cd}$ & $0.24 \pm 0.11^{b}$ & bdl & bdl & nd & nd & $20.34 \pm 1.61^{a}$ & $0.65 \pm 0.08$ \\
\hline $\mathrm{Cr}$ & $0.31 \pm 0.01^{b}$ & bdl & $1.23 \pm 0.30^{b}$ & nd & nd & $9.73 \pm 0.66^{\mathrm{a}}$ & $0.67 \pm 0.10$ \\
\hline $\mathrm{Pb}$ & bdl & bdl & bdl & nd & nd & bdl & bdl \\
\hline $\mathrm{Cu}$ & $1.77 \pm 0.15^{b}$ & $52.51 \pm 3.40^{\mathrm{a}}$ & $2.35 \pm 0.18^{\mathbf{b}}$ & nd & nd & $5.84 \pm 0.55^{b}$ & $6.41 \pm 0.68$ \\
\hline $\mathrm{Fe}$ & $15.37 \pm 2.27^{b}$ & $76.96 \pm 6.30^{\mathrm{a}}$ & $15.70 \pm 2.26^{b}$ & nd & nd & $7.90 \pm 0.29^{b}$ & $115.34 \pm 13.34$ \\
\hline $\mathrm{Mn}$ & $0.34 \pm 0.02^{c}$ & $2.61 \pm 0.26^{a}$ & $2.02 \pm 0.09^{a}$ & nd & nd & $1.09 \pm 0.23^{b}$ & $30.62 \pm 2.78$ \\
\hline $\mathrm{Zn}$ & $8.74 \pm 0.61^{b}$ & $18.31 \pm 3.89^{a}$ & $5.61 \pm 0.33^{b}$ & nd & nd & $40.86 \pm 3.64^{a}$ & $65.92 \pm 5.98$ \\
\hline
\end{tabular}

bdl, below detection limit; nd, not determined.

Values with non-common letter superscript are significantly different $(P<0.05)$.

tions of Mn, with no differences. There was a higher concentration of $\mathrm{Zn}$ in gonad than in other tissues but no significant difference was found with skin. The values obtained are similar to those obtained in O. bonariensis from farm 2 .

As and heavy metal concentrations in O. niloticus and fish feed from farm 4 are shown in Table 6. As and $\mathrm{Pb}$ concentrations in all tissues were below the detection limit and also in fish feed. The highest $\mathrm{Cd}$ concentration was found in scales, differing to the species above. In muscle, there was a lower $\mathrm{Cd}$ concentration and in the other tissues, values were below the detection limit. It is interesting to remark that $\mathrm{Cd}$ in muscle was only detected in $O$. niloticus. The presence of $\mathrm{Cd}$ was also detected in fish feed. The highest $\mathrm{Cr}$ concentration was observed in scales. Muscle and fat showed lower $\mathrm{Cr}$ concentrations and in liver was below detection limit. Fish feed showed $\mathrm{Cr}$ presence. It is interesting to remark that $\mathrm{Cr}$ was also accumulated in the scales of $O$. bonariensis from farm 2 and farm 3. Cu concentration showed differential accumulation in liver. The other tissues did not showed differences. This $\mathrm{Cu}$ distribution was also observed in $R$. quelen from farm 1 . The Fe concentration showed a similar pattern as $\mathrm{Cu}$ with higher concentration in liver, differing from the other tissues. The higher Mn concentration was observed in liver and fat and the lower in scale and muscle. Zn concentration was higher in scale and liver and lower in muscle and fat.

\section{Discussion}

According to the results obtained in this study, the different accumulation patterns may differ between species and also within species $(O$. bonariensis) due to farming practices and other factors (e.g. genetic, age and physiological state). The values obtained are similar to those found in available bibliography (Papagiannis et al. 2004; Lin et al. 2008; Uy- sal et al. 2008; Partridge \& Lymbery 2009; Yilmaz 2009; Minganti et al. 2010; Martins et al. 2011). However, it is important to remark that the values among these studies are highly variable because of many factors (e.g. species, age, feeding and water quality).

\section{Arsenic}

In this study, the As concentration showed a differential accumulation pattern; however, this pattern was different in each species. Rhamdia quelen showed higher values in muscle and lower in gonad and in liver while in O. bonariensis (farm 2), the higher concentration was found in liver and in $O$. bonariensis (farm 3) in skin.

Argentinean legislation limit for arsenic in food is $1 \mathrm{mg} \mathrm{Kg}{ }^{-1}$ (National Administration of Drugs, Food \& Medical Technology, ANMAT 2012), also UK Food Standards Agency (FSA 2012) proposed $1 \mathrm{mg} \mathrm{Kg}^{-1}$ as the statutory limit for commercial foods and the Canadian Guidelines for Chemical Contaminants and Toxins in Fish and Fish Products (Fish Products Standards \& Methods Manual 2005) establish a maximum of $3.5 \mathrm{mg} \mathrm{kg}^{-1}$. According to theses limits, the values obtained for $R$. quelen are below and should not cause any negative health effect.

The Joint Expert Committee on Food Additives (JECFA FAO/WHO 2010) determined a benchmark dose limit $\left(\mathrm{BMDL}_{0.5}\right)$ from epidemiological studies to be $3.0 \mu \mathrm{g} \mathrm{kg}^{-1}$ bw per day. In turn, the European Food Safety Authority Panel on Contaminants in the Food Chain (EFSA, CONTAM 2009), established a benchmark dose limit (BMDL ${ }_{01}$ ) between 0.3 and $8 \mu \mathrm{g} \mathrm{kg}^{-1}$ bw per day for inorganic arsenic. For a $70 \mathrm{~kg}$ person, the weekly intake would be between $0.147 \mathrm{mg} \mathrm{week}^{-1}$ and $3.920 \mathrm{mg} \mathrm{week}^{-1}$ for the lower and higher value, respectively. The highest value found in muscle in this study corresponds to $R$. quelen $\left(0.55 \mathrm{mg} \mathrm{kg}^{-1} \mathrm{ww}\right)$ so, a $70 \mathrm{~kg}$ person would have to 
consume $0.267-7.127 \mathrm{~kg}$ of fish muscle a week to pass the proposed limit. However, only a percentage of the total arsenic in fish is inorganic (1-5\%) (Brooke \& Evans 1981). Also, recently published articles are considering arsenic speciation in freshwater fish due to high amount of organic arsenic species when compared with inorganic arsenic. In some freshwater fish, it was observed that oxo-arsenosugarphosphate were the mayor arsenic compound (Schaeffer et al. 2006). In many salmonids, the main arsenic compounds found were arsenobetaine (AsB), which accounted for $92-100 \%$ of extractable arsenic (Slejkovec et al. 2004). If so, the values observed would be far below the BMDL. It is very important to highlight the fact that not taking into account the different species but considering total arsenic as being present exclusively as inorganic arsenic would lead to a considerable overestimation of the health risk related to dietary arsenic exposure (EFSA 2009). Arsenic speciation in freshwater fish species is becoming an interesting field for research when considering food safety. It is interesting to remark the high arsenic levels in the feed from farms 2 and 3; however, the effect over tissues of $O$. bonariensis is not the same. This could be the effect of different metabolic pathways related to the genetic origins of the specie. The $O$. bonariensis is found in wide variety of environments with different concentrations of natural arsenic up to $500 \mu \mathrm{g} \mathrm{L}^{-1}$.

\section{Cadmium}

Cd showed a differential accumulation pattern in liver in $R$. quelen and $O$. bonariensis from both farms (2 and 3 ) with similar concentration values. However, in $O$. niloticus, the $\mathrm{Cd}$ higher accumulation occurred in scales with a much higher value than the other species and was also detected in muscle. The scale accumulation pattern was observed for other species as an important processes for $\mathrm{Cd}$ excretion (Varanasi \& Markey 1978; Faucher et al. 2008). Nogami et al. (2000) found in commercial fish diets Cd concentrations of $0.3 \mathrm{mg} \mathrm{kg}^{-1}$ and $1.4 \mathrm{mg} \mathrm{kg}^{-1}$. These values resulted in a muscle concentration of $0.46 \pm 0.1 \mathrm{mg} \mathrm{kg}^{-1}$ and $0.6 \pm 0.1 \mathrm{mg} \mathrm{kg}^{-1}$ in viscera (Nogami et al. 2000). These values are within the range of the values obtained in this study. According to Zhou et al. (1998), metals are generally found in smaller amounts in muscle than in skin, gills and viscera in a study of $O$. niloticus in different natural environments. The maximum value allowed by the European Community (EC 2006) of $\mathrm{Cd}$ in muscle meat of fish is $0.05 \mathrm{mg} \mathrm{kg}^{-1}$ ww (wet weight). Moreover, the tolerable weekly intake (TWI) established by the EFSA (2009) is
$2.5 \mu \mathrm{g} \mathrm{kg}^{-1}$ bw (body weight) for $\mathrm{Cd}\left(150 \mu \mathrm{g} \mathrm{week}^{-1}\right.$ for a $60 \mathrm{~kg}$ person). Considering these recommendations, we found that the value in scales and in muscle exceeds the limit set by the European Community $\left(0.05 \mathrm{mg} \mathrm{kg}^{-1} \mathrm{ww}\right)$, and so consumption might lead to a risk for human health. When considering the TWI, more than $0.625 \mathrm{~kg}$ of fish muscle a week for a $60 \mathrm{~kg}$ person would have adverse effects. According to the Public Health Regulation (Hong Kong Government 1989) and the Hong Kong Center for Food Safety, the recommended $\mathrm{Cd}$ limit for consumption in muscle is $2.0 \mathrm{mg} \mathrm{kg}^{-1} \mathrm{ww}$. Given this value, the recorded values of $\mathrm{Cd}$ in muscle in this study do not exceed proposed limit.

\section{Chromium}

$\mathrm{Cr}$ accumulation in scales was observed in $O$. bonariensis (farm 2 and 3) and O. niloticus; however, in R. quelen the highest concentration was found in gonad. The $\mathrm{Cr}$ concentration in $O$. niloticus muscle $\left(0.30 \mathrm{mg} \mathrm{kg}^{-1} \mathrm{ww}\right)$ did not exceed the limit proposed by the Public Health Regulation (1.0 $\mathrm{mg} \mathrm{kg}^{-1}$ ww) (Hong Kong Government 1989). However, the value in fat $\left(1.32 \mathrm{mg} \mathrm{kg}^{-1} \mathrm{ww}\right)$ is over the proposed limit.

\section{Copper, iron, manganese and zinc}

$\mathrm{Cu}$ was observed in the analysed tissues from the three species. In $O$. bonariensis from farm 2 and 3, the accumulation distribution was variable. However, in $R$. quelen and $O$. niloticus, the higher values were found in liver. Although $\mathrm{Cu}$ is essential for human nutrition and health, high intake levels may cause problems (Demirezen \& Uruc 2006).

Fe was also observed in all tissues from the three species with higher values in liver due to the presence of transferrin and ferritin (Neves et al. 2009). The highest value was observed in liver of $R$. quelen.

Mn concentrations showed similar distribution in $O$. niloticus and $R$. quelen with the highest concentration in liver. Odontesthes bonariensis showed accumulation of $\mathrm{Mn}$ in scales with higher values than the other species. It should be noted that concentrations of $\mathrm{Mn}$ in the livers of $O$. bonariensis were similar to those found in $O$. niloticus and $R$. quelen.

$\mathrm{Zn}$ concentration showed a high variability between species; however, the concentration in muscle was similar. Rhamdia quelen and $O$. bonariensis from farm 3 showed higher concentration of $\mathrm{Zn}$ in gonad than in the other tissues. Papagiannis et al. (2004) observed a higher concentration of $\mathrm{Cu}$ and $\mathrm{Zn}$ in gonad than in muscle in four freshwater fish species. Also Sindayigaya et al. (1994) 
found higher levels of $\mathrm{Cu}$ and $\mathrm{Zn}$ in gonad than in muscle in two freshwater species.

Differential tissue accumulation of heavy metal is a very important factor in emerging aquaculture due to the implication on diet formulation. To reduce costs, small producers uses viscera and other parts of the fish of noncommercial value to prepare silage which is included in fish diets. This process should be of particular interest due to the bioaccumulation of heavy metals within the production.

\section{Conclusion}

This study was carried out as a first approach to understand trace metal accumulation from feed in farmed fish. All the results were below the limits proposed by EC (2001); FAO/WHO (2010) except for the concentration of $\mathrm{Cd}$ in muscle and scales of $O$. niloticus. However, the limit proposed by the Public Health Regulation (Hong Kong Government 1989) is higher, and if this limit is considered, the values obtained are below.

The variation of heavy metal concentration in tissues depends on the eating habits, time of exposure to different elements and metabolism of species. Although there is a wide range of international data of heavy metal values in fish, few are the relationships with accumulation patterns. Given the importance in food safety, further investigation should be necessary to establish guidelines and limits for human consumption.

The arsenic presence in fish edible tissue should be of particular interest due to the occurrence as a natural water pollutant in many regions of the world; however, the concentrations in this study were below the legal values. Furthermore, arsenic speciation should be of particular interest due to the lack of scientific information respect freshwater fish. At a regional level, the information in this emerging topic is scarce and so, further investigation should be emphasized. Research on nutrition and fish diet formulation will be the key for a responsible emerging aquaculture.

\section{Acknowledgements}

The authors thank UBA and CONICET for financial support. Also INTECH, Estación Hidrobilógica Chascomus and CENADAC for sampling support.

\section{References}

Alam, M.G.M., Tanaka, A., Allinson, G., Laurenson, L.J.B., Stagnitti, F. \& Snow, E. (2002) A comparison of trace element con- centrations in cultured and wild carp (Cyprinus carpio) of lake Kasumigaura, Japan. Ecotoxicol. Environ. Saf., 53, 348-354.

Brooke, P.J. \& Evans, W.H. (1981) Determination of total inorganic arsenic in fish, shellfish and fish products. Analyst, 106, 514-520.

Castro-González, M.I. \& Méndez-Armenta, M. (2008) Heavy metals: implications associated to fish consumption. Environ. Toxicol. Pharmacol., 26, 263-271.

Demirezen, D. \& Uruc, K. (2006) Comparative study of trace elements in certain fish, meat and meat products. Meat Sci., 74, 255-260.

Dural, M., Göks, M.Z.L. \& Özak, A.A. (2007) Investigation of heavy metal levels in economically important fish species captured from the Tuzla lagoon. Food Chem., 102, 415-421.

EC (2006) Official Journal of the European Union, Setting maximum levels for certain contaminants in foodstuffs. Commission Regulation (EC), No: 1881/2006.

EFSA (2009) Scientific opinion of the panel on contaminants in the food chain on a request from the European. Commission on cadmium in food. EFSA J., 980, 1-139.

EFSA Panel on Contaminants in the Food Chain (CONTAM) (2009) Scientific opinion on arsenic in food. EFSA J., 7, 1351.

FAO/WHO (1987) Principles of the Safety Assessment of Food Additives and Contaminants in Food Environmental Health Criteria, No: 70, FAO/WHO, Geneva.

Faucher, K., Fichet, D., Miramand, P. \& Lagardère, J.P. (2008) Impact of chronic cadmium exposure at environmental dose on escape behaviour in sea bass (Dicentrarchus labrax L.; Teleostei, Moronidae). Environ. Pollut., 151, 148-157.

Fish Products Standards and Methods Manual (2005) Appendix 3. Canadian Guidelines for Chemical Contaminants and Toxins in Fish and Fish Products. Available at: http://www.inspection.gc. ca/food/fish-and-seafood/manuals/standards-and-methods/eng/ $1348608971859 / 1348609209602 ? 7 \#$ s18c7

Food Standards Agency (2012) Web site online information http:// www.food.gov.uk/. The Arsenic in Food Regulations 1959 (S.I. [1959] No. 831), as amended by The Arsenic in Food (Amendment) Regulations 1960 (S.I. [1960] No. 2261) and The Arsenic in Food (Amendment) Regulations 1973 (S.I. [1973] No. 1052). The Stationery Office, London.

Gladyshev, M.I., Sushchik, N.N., Anishchenko, O.V., Makhutova, O.N., Kalachova, G.S. \& Gribovskaya, I.V. (2009) Benefit-risk ratio of food fish intake as the source of essential fatty acids vs. heavy metals: a case study of Siberian grayling from the Yenisei River. Food Chem., 115, 545-550.

Gordon Bell, J. \& Waagbø, R. (2008) Safe and nutritious aquaculture produce: benefits and risks of alternative sustainable aquafeeds. In: Aquaculture in the Ecosystem (Holmer, M., Black, K., Duarte, C.M., Marbà, N. \& Karakassis, I. eds.), 1st edn, Chapter 6, pp. 185-225. Springer, Berlin.

Herreros, M.A., Iñigo-Nuñez, S., Sanchez-Perez, E., Encinas, T. \& Gonzalez-Bulnes, A. (2008) Contribution of fish consumption to heavy metals exposure in women of childbearing age from a Mediterranean country (Spain). Food Chem. Toxicol., 46, 1591-1595.

Hong Kong Government (1989) Public Health and Municipal Services Ordinance, Food Adulteration (Metallic Contamination) Resolution, Ch. 132, Hong Kong Government, Hong Kong.

Ikem, A. \& Egiebor, N.O. (2005) Assessment of trace elements in canned fishes (mackerel, tuna, salmon, sardines and herrings) marketed in Georgia and Alabama (United States of America). J. Food Compos. Anal., 18, 771-787.

JECFA FAO/WHO (2010) Seventy-second report of the Joint FAO/WHO Expert Committee on Food Additives. Technical Report 959, 36. 
Kelly, B.C., Ikonomou, M.G., Higgs, D.A., Oakes, J. \& Dubetz, C. (2008) Mercury and other trace elements in farmed and wild salmon from British Columbia, Canada. Environ. Toxicol. Chem., 27, 1361-1370.

Lin, Y.H., Lin, S.M. \& Shiau, S.Y. (2008) Dietary manganese requirements of juvenile tilapia, Oreochromis niloticus $\times O$. aureus. Aquaculture, 284, 207-210.

Martins, C.I.M., Eding, E.H. \& Verreth, J.A.J. (2011) The effect of recirculating aquaculture systems on the concentrations of heavy metals in culture water and tissues of Nile tilapia Oreochromis niloticus. Food Chem., 126, 1001-1005.

Maunder, R.J., Buckley, J., Val, A.L. \& Sloman, K.A. (2011) Accumulation of dietary and aqueous cadmium into the epidermal mucus of the discus fish Symphysodon sp. Aquat. Toxicol., 103, 205-212.

Minganti, V., Drava, G., De Pellegrini, R. \& Siccardi, C. (2010) Trace elements in farmed and wild gilthead seabream, Sparus aurata. Mar. Pollut. Bull., 60, 2022-2025.

National Administration of Drugs, Food and Medical Technology, ANMAT (2012) Available at: http://www.anmat.gov.ar/alimentos/codigoa/Capitulo_III.pdf

Neves, J.V., Wilson, J.M. \& Rodrigues, P.N.S. (2009) Transferrin and ferritin response to bacterial infection: the role of the liver and brain in fish. Dev. Comp. Immunol., 33, 848-857.

Nogami, E.M., Kimura, C.C.M., Rodrigues, C., Malagutti, A.R., Lenzi, E. \& Nozaki, J. (2000) Effects of dietary cadmium and its bioconcentration in Tilapia Oreochromis niloticus. Ecotoxicol. Environ. Saf., 45, 291-295.

Papagiannis, I., Kagalou, I., Leonardos, J., Petridis, D. \& Kalfakakou, V. (2004) Copper and zinc in four freshwater fish species from Lake Pamvotis (Greece). Environ. Int., 30, 357-362.

Partridge, G.J. \& Lymbery, A.J. (2009) Effects of manganese on juvenile mulloway (Argyrosomus japonicus) cultured in water with varying salinity - implications for inland mariculture. Aquaculture, 290, 311-316.

Rosso, J.J., Puntoriero, M.L., Troncoso, J.J., Volpedo, A.V. \& Fernández Cirelli, A. (2011) Occurrence of fluoride in arsenicrich surface waters: a case study in the Pampa Plain, Argentina. Bull. Environ. Contam. Toxicol., 87, 409-413.
Schaeffer, R., Francesconi, K.A., Kienzl, N., Soeroes, C., Fodor, P., Váradi, L., Raml, R., Goessler, W. \& Kuehnelt, D. (2006) Arsenic speciation in freshwater organisms from the river Danube in Hungary. Talanta, 69, 856-865.

Schenone, N.F., Vackova, L. \& Fernández Cirelli, A. (2011) Fishfarming water quality and environmental concerns in Argentina: a regional approach. Aquacult. Int., 19, 855-863.

Sindayigaya, E., Cauwenbergh, R.V., Robberecht, H. \& Deelstra, H. (1994) Copper, zinc, manganese, iron, lead, cadmium, mercury and arsenic in fish from Lake Tanganyika, Burundi. Sci. Total Environ., 144, 103-115.

Slejkovec, Z., Bajc, Z. \& Doganoc, D.Z. (2004) Arsenic speciation patterns in freshwater fish. Talanta, 62, 931-936.

Sloth, J.J., Julshamn, K. \& Lundebye, A.-K. (2005) Total arsenic and inorganic arsenic content in Norwegian fish feed products. Aquac. Nutr., 11, 61-66.

Turkmen, M. \& Ciminli, C. (2007) Determination of metals in fish and mussel species by inductively coupled plasma-atomic emission spectrometry. Food Chem., 103, 670-675.

Uysal, K., Emre, Y. \& Köse, E. (2008) The determination of heavy metal accumulation ratios in muscle, skin and gills of some migratory fish species by inductively coupled plasma-optical emission spectrometry (ICP-OES) in Beymelek Lagoon (Antalya/Turkey). Microchem. J., 90, 67-70.

Van de Vis, H., Kestin, S. \& Robb, D. (2003) Is humane slaughter of fish possible for industry? Aquac. Res., 34, 211-220.

Varanasi, U. \& Markey, D. (1978) Uptake and release of lead and cadmium in skin and mucus of coho salmon (Oncorhynchus kisutch). Comp. Biochem. Physiol., 2, 187-191.

Yilmaz, F. (2009) The comparison of heavy metal concentrations $(\mathrm{Cd}, \mathrm{Cu}, \mathrm{Mn}, \mathrm{Pb}$, and $\mathrm{Zn})$ in tissues of three economically important fish (Anguilla anguilla, Mugil cephalus and Oreochromis niloticus) inhabiting Köycegiz Lake-Mugla (Turkey). Turkish. J. Sci. Technol., 4, 7-15.

Zhou, H.Y., Cheung, R.Y.H., Chan, K.M. \& Wong, M.H. (1998) Metal concentrations in sediments and tilapia collected from inland waters of Hong Kong. Water Res., 32, 3331-3340. 